\title{
Real Effective Exchange Rate Misalignment of the Tunisian dinar
}

\author{
Bouzid Amaira ${ }^{1}$
}

\begin{abstract}
In the Tunisian context, the issue of the misalignment of the real exchange rate has arisen for some time for some reason, a question that has intensified after the adoption of the floating regime. In this article, we will look at the assessment of the effects, if any, of the misalignment of the real effective exchange rate (REER) to its equilibrium value over the period from 1986 to 2015. The results show that the equilibrium level of the long-run exchange rate depends on productivity, the terms of trade and government spending. Two sub-periods are noted, that of a positive mismatch (undervaluation) from 1986 to 2003 followed by another negative mismatch (overvaluation) from 2004 to 2015. Such a result can be explained by the orientation of Tunisia towards the flexibility of the real exchange rate which in turn is likely to reduce the degree of imbalance of the real exchange rate. Similarly, the Tunisian authorities must adopt gradual reforms in their decisions on liberalization and financial integration and they are called upon to strengthen their trade and exchange policies to meet the challenge of the new international financial architecture. Finally, concerning the misalignment, we found the difference between the observed exchange rate and the equilibrium exchange rate is very low, especially since the implementation of the structural adjustment plan.
\end{abstract}

Keywords: Real equilibrium exchange rate, misalignment, exchange rate regime, Tunisia.

JEL Classification: E58, F31, F33

DOI: $10.24818 / \mathrm{REJ} / 2021 / 80 / 01$

\section{Introduction}

The equilibrium real exchange rate is a fundamental concept in an open economy. The deviation of the real exchange rate from its equilibrium level is called the real effective exchange rate (REER) misalignment. It has implications for economic activity. A review of the theoretical, as well as the empirical literature, shows that the imbalances of the real exchange rate are the source of any economic vulnerability of a country (Jongwanich, 2009). Indeed, real exchange rate imbalances are likely to affect the country's economic performance. Thus, the persistence of an overestimation of the real exchange rate is considered as a signal

\footnotetext{
${ }^{1}$ Doctor and Senior Economist at Tunisian Institute of Competitiveness and Quantitative Studies, Tunisia,am_bouzid@yahoo.fr, bouzid.amaira@itceq.tn 
of the crisis (Williamson 1983 and 1994, Stein and Allen, 1995). The real overvaluation reflects unfavorable macroeconomic conditions in the country, making them vulnerable to speculative attacks and currency crises. In this sense, Kaminsky and al. (1997) and Razin and Collins (1997) have pointed out that overvaluation of the real exchange rate is a sign of inconsistency in macroeconomic policy decisions which can lead to a current account deficit, an increase in external debt and risk of speculative attacks. On the other hand, the undervaluation of the real exchange rate strengthens competitiveness, stimulates investment and exports and improves the current account and economic growth. But, the persistence of real undervaluation can lead to adverse effects by exerting pressure on domestic prices and leading to misallocation of resources between the tradable and non-tradable sectors. Moreover, the determination of the equilibrium exchange rate is a difficult operation for two reasons: the first, it is necessary to calculate this equilibrium rate with great precision so that we can take the right macroeconomic decisions and the second, it is necessary to calculate the equilibrium rate. there is no single model required. However, the Purchasing Power Parity theory was the first approach used as a benchmark. The simplicity of this theory is explained by its frequent use in economic literature. But several shortcomings and limitations have been reported regarding the Purchasing Power Parity, mainly the idea that any variation in the real exchange rate must be interpreted by referring to the constancy of the real exchange rate as a deviation from the equilibrium level (Frait and Komárek, 2001). This view of the Purchasing Power Parity is no longer valid due to the non-stationarity of the real exchange rate. These critiques have led economists to seek alternative models of equilibrium real exchange rate that contribute to more effective policy analyzes. Many models have emerged, namely the FEER model (fundamental equilibrium exchange rate), BEER (behavioral equilibrium exchange rate), PEER (permanent equilibrium exchange rate) and NATREX (real exchange rate natural). What these theories have in common is that the equilibrium real exchange rate is not constant and is determined by its fundamental economic variables. However, these models cannot be applied to all countries. The size of the country and its weight in the international context determine the choice of model used for the calculation of the equilibrium real exchange rate. Therefore, in our case, we must choose a small country model applicable to Tunisia. The real effective exchange rate (REER) is the indicator reflecting the price competitiveness of an economy. It is made up of the nominal bilateral exchange rate and price levels. On the one hand, the direct calculation of the REER for a given country is not always simple because it is necessary to have certain information: i) determine the main partners of this country and consequently the bilateral exchange rates, ii) their weight in the country's trade and iii) their price levels. Also, to know its evolution, it is 
necessary to set a reference period. On the other hand, the indirect calculation of the real effective exchange rate is based on a precise model which can be used as a kind of check with the observed data. This brings up the phenomenon of misalignment. Thus, this note will be devoted to the various theoretical analyzes for calculating the real exchange rate equilibrium and to the analysis of the principle of misalignment. The analysis of the different theories of exchange rate determination (nominal and real) will be used to empirically decompose the misalignment of the real exchange rate and in particular to distinguish between periods of undervaluation and those of overvaluation.

Generally, there are two types of real exchange rate misalignment:

- The first type is macroeconomic in origin appears when the real effective exchange rate deviates from its equilibrium due to mistrust between macroeconomic policies (monetary and fiscal policies) and the official exchange rate regime.

- The second type is called structural misalignment occurs when there are changes in the real determinants of the equilibrium real exchange rate (REER) that are not transformed in the short run by real changes in REER.

In light of the importance of misalignment, we will assess the degree of misalignment of the real Tunisian dinar exchange rate using the Johanson cointegration and the error correction model for the adjustment between the short and long term. This leads us to explore the following questions: What is the equilibrium real effective exchange rate in Tunisia? Is the Tunisian dinar significantly misaligned? To answer these questions, our approach is organized as follows: a theoretical and empirical literature review is presented in Section 1. The evolution of exchange rate policy in Tunisia is described in Section 2. The empirical framework, data and econometric results are developed in Section 3. Finally, a conclusion and recommendations are presented in last Section.

\section{Theoretical and empirical literature review}

The Purchasing Power Parity (PPP) theory developed by Cassel $(1914,1923)$ is the widely used approach for determining exchange rates. It is based on the law of the single price and is based on perfect market arbitrage. This basic model had obtained aberrant results in developing countries (Balassa 1964, Rogoff 1996, Montiel, 2003) because the PPP approach assumes that the real exchange rate remains stable over the long term (Relative Purchasing Power Parity approach). However, there are traditional theories of exchange rate determination such as the elasticity approach (Robinson, 1937), the monetary approach (Frankel and Mussa, 
1976), the interest rate parity (Keynes, 1936) and portfolio balance (Branson, Halttunen and Masson, 1977). Other theories such as the models of Coudert (1999) which rely on the effect of Samuelson and debt to determine the equilibrium exchange rate. Cashin and al. (2003) developed a long-run equilibrium exchange rate for commodity-exporting countries. They found that real commodity prices and the real exchange rate move together in the long run. Also, Montiel and Ostry (1993) proposed a model based on the parallel market premium, but they considered the latter as a reliable indicator of the sign and magnitude of misalignment of the real exchange rate. However, there are new theories of exchange rate determination such as FEER, NATREX, BEER and Edwards' model. First, the Fundamental Equilibrium Exchange Rate (FEER), developed by Williamson (1994), is the rate that should generate a current account balance equal to the underlying capital flows during the cycle without trade restrictions, internal balance in progress. Then, the Natural Real Exchange Rate (NATREX), developed by Stein (1994), Stein and Lim (1995), is the rate that generates a current account balance that corresponds to the equilibrium between the optimal investment and savings while the unemployment rate is at its natural level. Then, the Behavioral Equilibrium Exchange Rate (BEER) is developed by Clark and Mac Donald (1998, 2000). The latter calculates the rate which is determined during the long-term relationship between the exchange rate and its determinants: the interest rate differential, the term of the exchange, differential productivity, net foreign assets and public debt. Finally, Edwards (1987, 1989, 1992 and 1994) presented pioneering work to determine the equilibrium exchange rate in developing countries. He defined the Equilibrium Real Exchange Rate (REER) as the relative price of tradable goods concerning non-tradable goods which results in the simultaneous achievement of the external and internal equilibrium of the economy. Edwards's model allows both real and nominal factors to play a role in the short term, but only fundamental factors affect the REER in the long term. Elbadawi (1994) adopted the concept of REER and used the cointegration approach to estimate the case of Chile, Ghana and India between the period 1965-1990. Also, there are other theories to define the REER and assess misalignments such as the permanent equilibrium exchange rate developed by Gonzalo and Granger (1995), the desired equilibrium exchange rate proposed by Bayoumi and al. (1994) and the International Monetary Fund (2008, 2013) have developed a new scientific method "the macroeconomic equilibrium approach" and supplemented by the "external sustainability approach". Misalignment or over/under evaluation is defined as the gap between the observed real exchange rate and the equilibrium real exchange rate. Also, this equilibrium rate should be defined. The equilibrium real exchange rate model will make the non-stationary real exchange rate dependent on non-stationary 
fundamentals. The literature offers several theoretical approaches. In this work, we chose to retain the NATREX (Natural Real Exchange Rate) model developed by Stein (1994) and adapted to the case of a small open economy (Lim and Stein, 1995). NATREX differs primarily from Williamson's (1983) (Fundamental Equilibrium Exchange Rate, FEER) approach in its positive character (Allen, 1995). Unlike the FEER model, it is not necessary to define a sustainable and/or desirable external balance. Many empirical studies have been carried out on the problems of the misalignment of the real exchange rate in the Middle East/North Africa countries and developing countries. Mongardini (1998) predicts an equilibrium real exchange rate for Egypt using the Edwards model 1989-1996. Its conclusions consist of an overvaluation over the entire period. The Egyptian pound real exchange rate peaked at $35 \%$ in 1989 and the real exchange rate decline to approach equilibrium in 1995. Lahcen (2001) estimated the REER for five countries in the region namely: Algeria, Morocco, Tunisia, Egypt and Turkey during the period from 1985 to 1997 by applying the Edwards model $(1989,1994)$ and Elbadawi (1994). He used a cointegration method to see if there is a longterm relationship between the REER and its fundamentals. According to their results, the five countries in the region presented an overestimation of their REER. Especially for Algeria, after 1987, there was a significant overvaluation due to the worsening of the terms of trade (sharp drop in oil industry revenues in 1986) and also to the budget deficit which was financed by money creation resulted in an overvaluation of the REER of around 66\% in 1989 and $56 \%$ in 1990. Despite the improvement in the oil sector, REER remained overvalued at $6 \%$ in 1997. Koranchelian (2005) by applying the model of Cashin and al. (2003), defined the REER of Algeria according to the relative productivities between exchangeable goods and non-exchangeable goods and the terms of trade (composed mainly by revenues from the hydrocarbon sector). He assessed the degree of misalignment during the period 1970-2003. He concludes that the REER was considerably overvalued between 1983-1992 and returns to its equilibrium in 2002-2003. Boileau and al. (2007) applied the model of Cashin and al. (2003) in the Algerian case (1970-2007). They assumed that the REER was explained by three important factors: the real price of the primary commodity (the world price of oil), the productivity differential, and government spending. They found that all of these factors appreciate the Algerian REER, however, the increase in government spending has been associated with a relatively small appreciation of the real effective exchange rate because the important properties of capital spending are directed towards imported goods. Charfi (2008) estimated a REER for Tunisia (1983-2000) and assessed the degree of misalignment using the Edwards model and the cointegration method to see if there is a long-term relationship between the real effective exchange rate and its fundamentals. She 
found that the REER was overestimated between 1989 and 1997. Hasanov (2009) estimated the REER using several methods: The Purchasing Power Parity, the macroeconomic equilibrium, the Behavioral Equilibrium Exchange Rate and the permanent real exchange rate. He found that relative productivity, trade openness, net assets abroad, government spending, and oil prices are the main determinants of misalignment. The IMF (2012) used the Consultative Group on Exchange Rate Issues (CGER) method to assess the degree of misalignment of the equilibrium real exchange rate in Algeria. He found that the REER was determined by the terms of trade, the output gap per worker in Algeria vis-à-vis its trading partners (productivity) and government spending. The analysis suggests that the REER was overvalued between (1984-2002) and reached the equilibrium level after 2010.

\section{The exchange rate policy in Tunisia}

Since its independence, Tunisia has adopted essentially two exchange rate policies since the collapse of the Bretton Woods system. From 1973 until 1986, Tunisia preferred a fixed exchange rate policy, in particular, it applied a conventional fixed parity regime. During this period, the exchange rate went through five phases (Safra and Ben Marzouka, 1987):

- First phase from 1973 to 1978: the Tunisian authorities chose the German Deutsche Mark as reference currency following the significant instability of the French franc.

- Second phase from 1978 to 1981: Tunisia adopted, from 1978, the principle of anchoring to a basket of currencies to avoid suffering the fluctuations of a single currency. During this period, it fixed its currency at the French franc, the German Deutsche Mark and the US dollar. The monetary authorities also considered the availability of foreign currency.

- Third phase from 1981 to 1984: the fall in the price of oil and the export promotion policy prompted the Tunisian monetary authorities to extend the basket to other currencies depending on the structure of the trade.

- Fourth phase from 1984 to 1985: following the real appreciation of the Tunisian dinar, Tunisia decided to once again expand its basket of currencies and the dinar exchange rate was now also linked to the currencies of competing countries. This policy aimed to promote exports and improve Tunisian competitiveness.

- Fifth phase from 1985 to 1986: the succession of the recession and the problems of the balance of payments pushed the Tunisian authorities to change the weightings of the currencies. These corrections were ineffective (balance of payments crisis) forcing the authorities to devalue the currency by 10\% in 1986 (Hanna, 2001). Since the devaluation of 1986, Tunisia has applied 
an intermediate exchange rate policy; it has set up a regime with movable fluctuation bands. Indeed, the exchange rate was anchored to a basket of currencies with a fluctuation band; the central rate and the fluctuation band were determined according to the objectives and inflation.

- From 1986 to 1989, under the structural adjustment plan, the Tunisian Central Bank lowered the nominal effective exchange rate gradually until the real effective exchange rate reached its equilibrium level to gain in terms of competitiveness. (Domaç, Shabsigh, 1999).

- During the 1990s, the nominal effective exchange rate was determined in such a way as to keep the real effective exchange rate constant; the monetary authorities aimed to preserve competitiveness (Fanizza and al, 2002). During this decade, an interbank spot exchange market was created in 1994 and forward in 1997. Resident and non-resident authorized intermediaries were authorized to act as counterparties in forwarding exchange transactions on behalf of their own. resident customers for import operations of goods and services and financial operations for a maximum period of 12 months and export operations for a maximum period of 9 months.

- Since 2001, Tunisia has widened the fluctuation band of the nominal exchange rate. This policy was put in place to apply the IMF recommendations aimed at relaxing the exchange rate policy (Fanizza and al, 2002) to improve competitiveness.

- Since 2012, more flexible management of the exchange policy was introduced by the Tunisian Central Bank 2012. It consists of determining its reference exchange rate based on the average exchange rate on the interbank market and not based on a fixed basket of currencies. It intervenes in the foreign exchange market through bilateral transactions when market quotations undergo substantial deviations from the daily fixing. Thus, it can be concluded that, since the collapse of the Bretton Woods system, Tunisia's main objective was to maintain or improve external competitiveness to support its balance of payments and, more specifically, its current account. Given that the external demand for the products imported from the country is very price elastic, it is proposed to measure Tunisian competitiveness by the misalignment of the real effective exchange rate to verify whether the exchange target has been reached. 


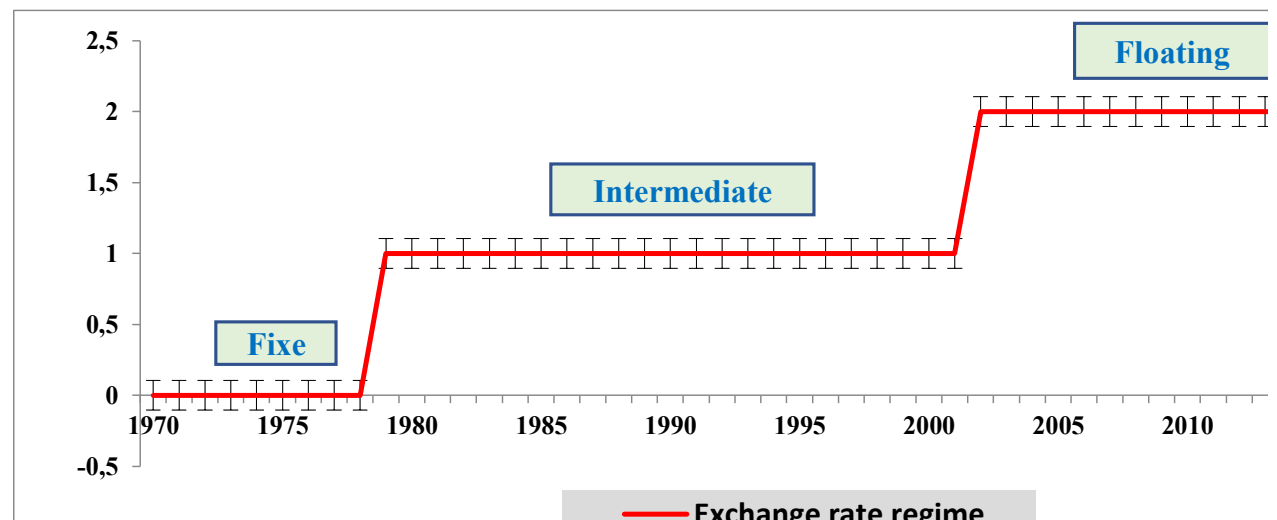

Figure 1. Exchange rate regime in Tunisia Source: Author's compilation

According to the Central Bank of Tunisia, the exchange rate regime since 2001 has been characterized by the adoption that of the administered float.

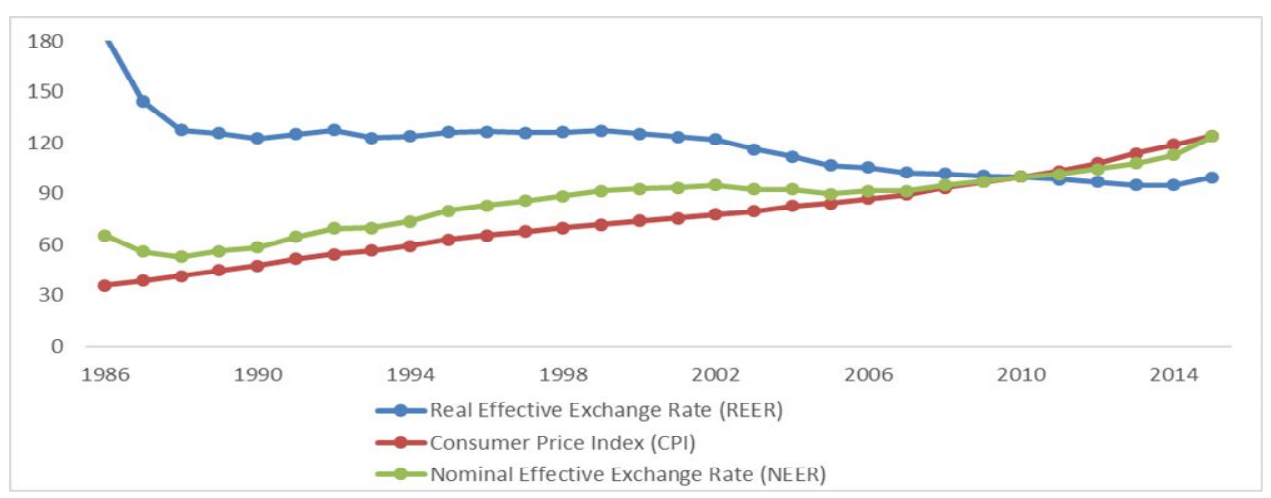

Figure 2. Evolution of the REER, the CPI and the NEER

Source: Author's compilation

Figure 2, shows that since the devaluation of 1986, the real effective exchange rate has not been constant but has revolved around a constant average. Targeting a constant real effective exchange rate can generate inflationary effects that can lead to monetary authorities losing control over inflation (Adams and Gros 1986, Montiel and Ostry 1991). This scenario was posed by the Tunisian monetary authorities after the revolution of December 2010 to the extent that the inflation rate reached $5.8 \%$ in 2013 close to the rate which was recorded in 1986 of $6.16 \%$. This can be explained by the presence of significant shocks over the period, and 
imprudent macroeconomic policy of Policy mix, flexible prices and wages. After the devaluation of 1986, the Tunisian authorities targeted a constant real effective exchange rate to preserve the competitiveness of the economy abroad. Indeed, it was a matter of letting the value of the dinar depreciate so that the depreciation compensates for the difference between the domestic inflation rate and the foreign inflation rate.

This change in the exchange rate regime was prudent and took place in several stages:

- gradual relaxation of exchange controls by reducing the central bank's intervention in the exchange market;

- creation in 1994 of a spot foreign exchange market and this was extended in 1997 to forward foreign exchange transactions;

- current convertibility of the dinar from 1993 which implies freedom to settle current expenditure in foreign currency by the various economic agents;

- relaxation of exchange controls on capital operations to encourage foreign investment;

- improvement of the exchange risk hedging system for commercial transactions. The possibilities of hedging the exchange risk were added in 2001.

- from January 02, 2012, launch of a new Tunindex20 index representing the performance of the 20 largest market capitalizations most active on the market.

\section{* Measurement of REER misalignment}

The purpose of this subsection is first to describe the method and present the results of the calculation of real effective exchange rate imbalances and then to analyze the extent of the misalignment. Indeed, one of the objectives of determining the fundamentals of the real exchange rate is to measure the deviation of the real effective exchange rate from its equilibrium value. To measure the degree of misalignment, we use the long-run static equation to obtain the estimated values of the equilibrium real exchange rate. The equilibrium real exchange rate is represented by the permanent component of the filtered real effective exchange rate series. The misalignment or deviation from the equilibrium of the REER is calculated as follows:

$$
\text { Mtsaltgnment }=\frac{Q^{\text {Observed }}-Q^{\text {Estimated }}}{Q^{\text {Estimated }}}
$$


Where $\mathrm{Q}^{\text {Observed }}$ denotes the real exchange rate index and $\mathrm{Q}^{\text {Estimated }}$ denotes the real exchange rate estimated from long-run equilibrium relationships.

$>$ If Misalignment $=0 \%$, the observed real effective exchange rate aligns with its equilibrium level, there is no real exchange rate imbalance.

$>$ If Misalignment $>0 \%$, this reflects an overvaluation of the Tunisian dinar where the real effective exchange rate exceeds its equilibrium level. This situation corresponds to a decrease in the attractiveness of Tunisian products on the international market given their prices. This results in a drop-in export earnings and an increase in the country's imports with consequences on the level of investment, external and domestic payments, production and domestic demand.

$>$ If Misalignment $<0 \%$, this reflects a real undervaluation of the Tunisian dinar. This situation corresponds to an increase in sales of Tunisian products on the international market and thus to an increase in export earnings and a decrease in imports. Undervaluation is not a problem when managed well. However, it leads to a situation of excess supply of dinars, excess liquidity which can lead to consequences such as the rapid increase in the money supply, inflation, etc., which can adversely affect the competitiveness of the economy.

\section{Econometrics studies}

This section is devoted to the presentation of the methodology used and to the interpretation of the estimation results. The estimation of the empirical model took place in three steps: the first step is to perform unit root tests on each of the model variables to ensure the econometric approach to be followed, the second step is to verify the existence of a cointegrating relationship between the real exchange rate and its fundamentals and the third step is to estimate an errorcorrecting model based on the cointegration relationship found. The study covers a period from 1986 to 2015. It was from 1986 that Tunisia devalued the dinar. All the original series have been transformed into a natural logarithm which makes it possible, among other things, to verify the characteristics of the short-term and long-term partial elasticities of the model, under the assumption of an exponential exchange rate function of fundamentals of the economy.

\section{a. Presentation of the theoretical model and the variables used}

We are developing a simple macroeconomic model for determining the long-term RER intended for emerging countries, and particularly for Tunisia. The proposed model is inspired by theoretical behavioral models of the NATREX (Natural Real Exchange Rate) type developed by Stein and Allen (1995) or BEER (Behavior 
Equilibrium Exchange Rate) proposed by Clark and MacDonald (1998) or the REER (Real Equilibrium Exchange Rate) proposed in the works of Edwards (1989) and Elbadawi (1994). The long-term real exchange rate represents the real exchange rate which ensures internal and external balance. The equations which explain the conditions, constitute a global equilibrium model which represents the internal functioning of the economy, with its demand and supply side, and its relation with the outside world. The algebraic expression of the real exchange rate that we apply is of the following type:

$$
\boldsymbol{R E R}=\frac{\boldsymbol{P}}{E \cdot P^{*}}
$$

Where RER designates the real exchange rate, $\mathrm{P}$ denotes the domestic price index, $\mathrm{P} *$ represents the foreign price index. $\mathrm{E}$ is the nominal exchange rate defined with uncertainty (Number of units of domestic currency exchanged for one unit of foreign currency). Thus, according to our definition, an increase (decrease) in the real exchange rate means a real appreciation (depreciation). We present the theoretical formula applied to our model where the RER is expressed as a function of a battery of variables likely to influence it:

$$
R E R_{t}=\beta_{0}+\beta_{1} V_{1 t}+\beta_{2} V_{2 t}+\ldots \ldots \ldots+\beta_{n} V_{n t}+e_{t}
$$

Where RER is the real exchange rate, $\beta$ are the coefficients to be estimated, $V$ is the $\mathrm{N}$ chosen independent variables; $\beta_{0}$ is a constant and $\mathrm{e}$ is white noise.

More explicitly, the long-term relationship to be tested for the RER according to its fundamentals is written as follows:

$$
\boldsymbol{R E R}_{t}=\beta_{0}+\beta_{1} \text { Te }_{t}+\beta_{2} \text { Opnes }_{t}+\beta_{3} \text { Prod }_{t}+\beta_{4} \text { Debt }_{t}+\beta_{5} \text { Dep }_{t}+e_{t}
$$

Where RER denotes the real exchange rate, Te: the terms of trade, Opnes: trade openness, Debt: the ratio of external debt to GDP and Dep: the ratio of public expenditure to GDP; Prod: productivity measured by real GDP per capita. Theoretically, the real exchange rate is explained by its fundamentals as follows: The term of the trade ( $\mathrm{Te})$ : The terms of trade are equal to the ratio between export prices (unit value index) and import prices (unit value index). They sometimes have a positive and sometimes a negative influence on the real effective exchange rate (Devarajan and al., 1998). Deterioration in the terms of trade generally has two effects: an income effect linked to the decline in the consumer's real income and a substitution effect of foreign goods by domestic goods. If the income effect is dominant, the real exchange rate depreciates as the country 
reduces the production of domestic goods and increases that of exported goods. On the other hand, when the substitution effect is more powerful, the real exchange rate tends to appreciate and exports decrease. This promotes the production of substitute domestic goods. The demand for non-tradable goods is increasing and their prices are rising. But the improvement in the terms of trade always leads to an appreciation of the REER, due to the trade surplus due to an income effect more dominant than the substitution effect. And this is so in most developing countries because the income effect is preponderant there (Edwards, 1988; Baffes and al., 1997). We can expect the coefficient of the term variable of trade to be negative. The effect of trade openness (Opnes): Theoretically, several models have analyzed the impact of trade openness on the real exchange rate. The literature shows that the equilibrium real exchange rate is a function of observable macroeconomic variables and that the real exchange rate approaches its equilibrium rate over time. The increase in openness, expressed as the sum of exports and imports to GDP, leads to a strong movement of currencies. This openness rate, for developing countries, is marked by a greater increase in imports. Thus, a fall (rise) in the opening may appreciate (depreciate) the real exchange rate. External debt (Debt): Informs us about the real stock of foreign exchange reserves. The influence of external debt on the REER stems from the fact that faster growth in public expenditure relative to the revenue increases the budget deficit. This causes upward pressure on the prices of non-tradable goods relative to the prices of tradable goods. This increase in the relative price of nontradable goods, in turn, leads to an appreciation of the REER (Haberger, 1986). The coefficient assigned to this variable should be negative. Public expenditure (Dep): Theoretically, the effect of government expenditure on the real exchange rate is still ambiguous. The impact of public spending depends on the relative importance of tradable and non-tradable goods in the economy. To illustrate this effect, Edwards (1989) considers two periods' $t_{1}$ and $t_{2}$ and he assumes that tax distortions do not exist. Assuming an increase in the consumption of non-tradable goods by the government at the period $t_{1}$, financed by public or international borrowing. The real exchange rate is affected in two ways. In the first phase, the increase in demand for goods and services leads to an increase in the prices of non-tradable goods. This price increase causes the real exchange rate to appreciate. However, the government will increase the level of taxes to pay off its debt. This provision reduces the level of disposable income and consequently will lead in period $t_{2}$ to a fall in aggregate demand which results in a fall in the prices of non-tradable goods, hence depreciation of the real exchange rate. On this, it is difficult to determine a priori the impact of a change in government consumption of non-tradable goods on the real exchange rate. The same situation is obtained by analyzing the effect of changes in the consumption of tradable goods by the 
government on the real exchange rate. Productivity (Prod): The effect of relative productivity should be positive because an increase in it leads to an improvement in the competitiveness of the economy, which should result in a real depreciation.

\section{b. Econometric techniques: The Error Correction Model}

The stationarity test applied to the different variables of our model shows that the variables are stationary indifference with different specifications. The presence of a unit root implies that direct estimation by the method of Ordinary Least Squares (OLS) is likely to lead to spurious estimates. As a result, the use of the Error Correction Model (ECM) is more appropriate. The estimation procedure consists in testing the existence of a cointegration relationship between the equilibrium exchange rate and its fundamentals, in estimating the short-term and long-term equation and in checking the conditions of validity of the equations. Using the error correction model shows the common cointegrating relationship (the common trend) and infers the interactions between the variables. Let us estimate the error correction model according to the representation of Hendry's model, following by the one-step least squares method. Thus, the equation of the error correction model is written:

$$
\begin{aligned}
D\left(\text { LREER }_{t}\right)= & \beta_{0}+\beta_{1} D\left(\text { LOpnes }_{t}\right)+\beta_{2} D\left(L D p_{t}\right)+\beta_{3} D\left(\text { LDebt }_{t}\right) \\
& +\beta_{4} D\left(\text { LProd }_{t}\right)+\beta_{5} D\left(\text { LTe }_{t}\right)+\beta_{6} D\left(\text { LREER }_{t-1}\right)+\beta_{7} D\left(\text { LProd }_{t-1}\right) \\
& +\beta_{8} D\left(\text { LTe }_{t-1}\right)+\beta_{9} D\left(\text { Lopnes }_{t-1}\right)+\beta_{10} D\left(\text { LDebt }_{t-1}\right) \\
& +\beta_{11} D\left(\text { LDp } p_{t-1}\right)+\varepsilon_{t}
\end{aligned}
$$

$D:$ is the first difference operator defined by $D\left(X_{t}\right)=X_{t}-X_{t-1}$ The coefficients $\beta_{1}$, $\beta_{2}, \beta_{3}, \beta_{4}$ and $\beta_{5}$ represent the short-term dynamics and the coefficients $\beta_{7}, \beta_{8}, \beta_{9}$, $\beta_{10}$ and $\beta_{11}$ characterize the long-term equilibrium. The coefficient $\beta_{6}$ is the error correction coefficient, it must be less than unity and negative. The error correction coefficient indicates the speed of adjustment of the endogenous variable of gross domestic product (LREER) to return to long-term equilibrium following a shock. The coefficient $\beta_{0}$ represents the constant of the model.

The short-term elasticities are: $\beta_{1}, \beta_{2}, \beta_{3}, \beta_{4}$ and $\beta_{5}$

The long-term elasticities are: $-\frac{\beta 7}{\beta 6},-\frac{\beta 9}{\beta 6},-\frac{\beta 9}{\beta 6},-\frac{\beta 10}{\beta 6}$ and $-\frac{\beta 11}{\beta 6}$ 
Table 1. Short and long-term elasticities of the real equilibrium exchange rate

\begin{tabular}{|c|c|c|}
\hline Variables & Short-term elasticity & Long-term elasticity \\
\hline LDp & $-0,097$ & $-0,226$ \\
\hline LDebt & 0,029 & 0,315 \\
\hline LOpnes & $-0,082$ & $-0,066$ \\
\hline LProd & $-0,085$ & $-0,282$ \\
\hline LTe & $-0,156$ & $-0,470$ \\
\hline
\end{tabular}

Source: Author's compilation

Before any estimation, it is necessary to ensure that there is a cointegrating relationship between the real exchange rate and its fundamentals. The Johansen cointegration technique was used for this purpose. The results confirm that there is indeed a cointegration relationship between the equilibrium real exchange rate and its retained fundamentals.

\section{c. The empirical estimation of the model}

To ensure the reliability of our econometric results, we used White's method to correct any possible heteroskedasticity. The application of the LM test of Breusch and Godfrey led to reject the null hypothesis of the absence of autocorrelation of the residuals at the $5 \%$ threshold. Regarding the conditions of validity of our estimate, the application of the Johansen test made it possible to highlight a cointegration relationship between the model variables. Also, the error correlation coefficient is negative and less than unity in absolute value. It is also statistically different from zero at the 5\% level. The signs are consistent with theoretical predictions. Based on the results reported below, The $\mathrm{R}^{2}$ and the adjusted $\mathrm{R}^{2}$ are quite large and therefore reflect a fairly good quality of the regression. Likewise, the ratio of the F-statistic shows that taken together, the coefficients of the independent variables are statistically different from zero at the $1 \%$ level. These results suggest that the estimated model can be considered as satisfactorily describing the short and long-term behaviors of Tunisia's equilibrium real exchange rate.

Table 2. Estimation of a reduced real exchange rate model

\begin{tabular}{|c|c|c|c|}
\hline \multicolumn{4}{|c|}{ Dependent Variable D(LREER) } \\
\hline Explanatory variables & Coefficient & t-Statistic & Prob. \\
\hline C & 5.036287 & 2.869741 & 0.0106 \\
\hline D(LOpnes) & -0.081952 & -0.892244 & 0.3847 \\
\hline D(LDp) & -0.097043 & -0.804846 & 0.4320 \\
\hline D(LDebt) & 0.029663 & 0.199479 & 0.8443 \\
\hline D(LProd) & -0.085231 & -0.347573 & 0.7324 \\
\hline D(LTe) & -0.155829 & -1.096386 & 0.2882 \\
\hline
\end{tabular}

Year XXIV no. 80

June 2021 


\begin{tabular}{|c|c|c|c|}
\hline \multicolumn{4}{|c|}{ Dependent Variable D(LREER) } \\
\hline Explanatory variables & Coefficient & t-Statistic & Prob. \\
\hline LREER(-1) & $\mathbf{- 0 . 5 5 7 0 1 7}$ & $\mathbf{- 4 . 5 7 3 0 5 1}$ & $\mathbf{0 . 0 0 0 3}$ \\
\hline LProd(-1) & -0.157017 & -2.740884 & 0.0139 \\
\hline LTe(-1) & -0.262062 & -4.382071 & 0.0004 \\
\hline LOpnes(-1) & -0.037235 & -0.304973 & 0.7641 \\
\hline LDebt(-1) & 0.176945 & 1.744979 & 0.0990 \\
\hline LDp(-1) & -0.126458 & -0.937164 & 0.3618 \\
\hline $\mathrm{R}^{2}$ & 0.903345 & F-statistic & 14.44400 \\
\hline $\mathrm{R}^{2}$ ajusté & 0.840804 & LM Test & 0.953228 \\
\hline $\mathrm{DW}$ & 1.568482 & White Test & 0.884751 \\
\hline \multicolumn{2}{|c}{ Source: Author's compilation } \\
\end{tabular}

\section{d. Interpretation of estimation results}

This involves identifying the main determinants of the equilibrium real exchange rate on the one hand, and calculating and measuring the level of misalignment of the Tunisian dinar on the other hand.

\section{i. Main determinants of the short and long-term equilibrium exchange rate}

In the context of the long-term dynamics of the equilibrium real exchange rate, the results are presented in Table 1. For the impact of public consumption on the real value of the Tunisian dinar, the results obtained contradict what predicted theoretical analyzes. We have found that an increase in government demand leads to an appreciation of the real exchange rate. Among the explanations, we can retain the one predicting that a significant crowding-out effect may translate into a decline in private demand for non-tradable products. When public consumption leans more towards non-tradable goods, then an expansionary fiscal policy implies an increase in taxes and interest rates and the consequence will be a decrease in private expenditure on non-tradable goods. For the terms of trade, their improvement leads to an appreciation of the real exchange rate implementing an income effect that dominates the substitution effect. Thus, a $10 \%$ increase in the terms of trade generates almost a $1.6 \%$ appreciation of the real value of the Tunisian dinar. The effect of per capita income on the real exchange rate contributes to long-term changes in the real exchange rate. However, the coefficient attributed to it has a negative sign, which is compatible with theoretical predictions. However, the effect of the Balassa-Samuelson phenomenon is all the more marked as the country is underdeveloped (Coudert, 1999), which is the case for Tunisia. As the evolution of the real exchange rate in Tunisia indicates, it has an appreciation proper between 1986 and 2015. Thus, Tunisia benefits from 
productivity gains and the service sector tend to increase during its development process, which explains the sign attributed to the coefficient of the BalassaSamuelson effect. As, in the model tested by Edwards (1994), technical progress causes an appreciation of the equilibrium real exchange rate but the effect is however statistically significant. Our empirical results also lead to this conclusion. This result is expected with what is observed in general (an appreciation). However, for Tunisia, any productivity gains are realized in the tradable goods sector. The increase in debt (Ldebt) is a source of real equilibrium depreciation (a positive sign). Regarding the short-run dynamics of the equilibrium real exchange rate, it was examined by estimating an error correction model (ECM) and the results noted are shown in Table 2. These results show that the short-run dynamics of this variable do not differ from that of the behavior of the equilibrium real exchange rate in the steady-state. Indeed, all the estimated variables exert on the REER the same effects already found in the long-term relationship. The coefficient assigned to the error correction term is negative and less than unity $(-0.557)$ and it is significant, which is in line with theoretical predictions. The model fit coefficient being at -0.557 , means that $55.7 \%$ of the deviation of the REER from its equilibrium, during a given year, is corrected in the following year. This suggests that the exchange rate tends to quickly revert to its stationary long-term equilibrium if there is a shock. The model manages to adjust $55.7 \%$ of the imbalance between the desired and effective levels of the real exchange rate. This observation makes it possible to determine the number of years necessary to eliminate a given exogenous shock. The formula for the rate of adjustment in years is as follows:

$$
1-\left|V_{a}\right|^{t}=1-\rho
$$

t: the number of years to calculate; $\mathrm{V}_{\mathrm{a}}^{\mathrm{t}}$ : the speed of adjustment; $\mathrm{Q}$ : the magnitude of the shock.

$$
\begin{aligned}
& 1-|-0,557|^{t}=1-0,05 \Rightarrow 1-|-0,557|^{t}=0,95 \Rightarrow|-0,557|^{t}=0,05 \Rightarrow \\
& t .(\log |-0,557|)=\log (0,05) \\
& \Rightarrow t=\frac{\log (0,05)}{\log |-0,557|}=5,12 \text { ans }
\end{aligned}
$$

Thus, removing $99 \%$ of a real exchange rate shock takes an average of five years.

Year XXIV no. 80

June 2021 


\section{ii. Fundamental equilibrium real exchange rate and misalignment of the Tunisian dinar}

First of all, it should be remembered that the long-term REER is obtained from the long-term relationship of the error correction model. The fundamentals retained in the model and the long-term residuals are decomposed using the Hodrick-Prescott filter to eliminate the cyclical part in the evolution of the equilibrium exchange rate. The equation of the equilibrium exchange rate can be written as follows:

\section{LREER $=0.315 *$ LHPDebt $-0.282 *$ LHPProd $-0.47 *$ LHPTe + LHPResid}

Where $\mathrm{L}$ denotes the logarithm and HP denotes the trend of the variable using the Hodrick-Prescott filter. The following graph shows the evolution of the two real exchange rates, observed and estimated over the period from 1986 to 2015, when the real effective exchange rate goes below (above) the equilibrium real exchange rate. (estimated), this means that the real exchange rate is overvalued (undervalued).

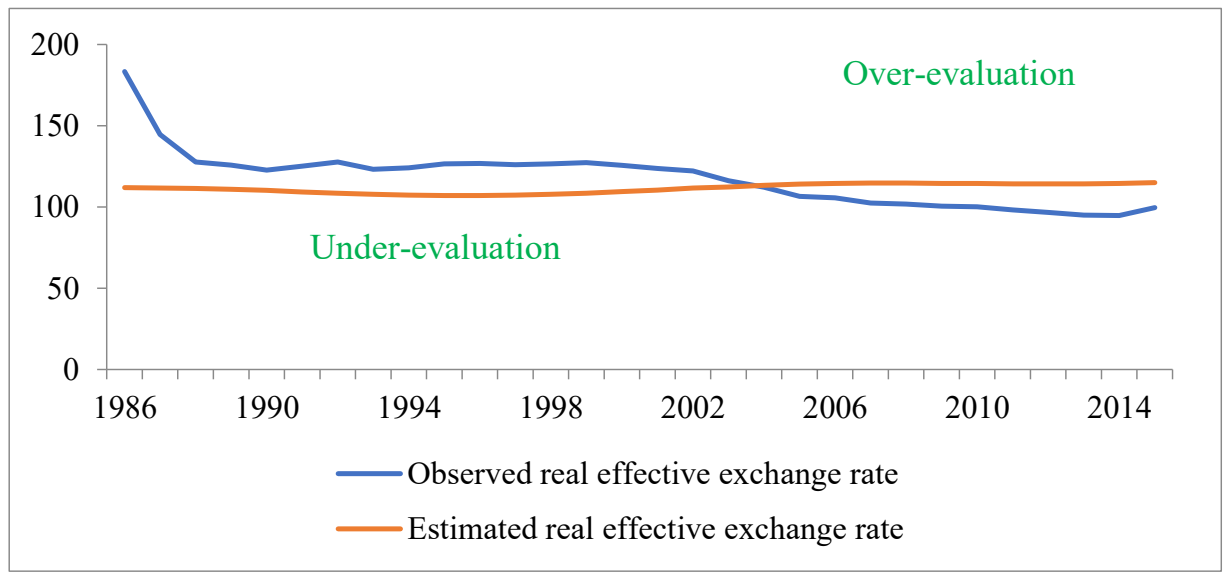

Figure 3. Real equilibrium exchange rate of the Tunisian dinar Source: Author's compilation

According to the figure below, we observe that the adoption of a policy of gradual depreciation of the Tunisian dinar resulted in an undervaluation of this currency by up to $15 \%$ in 1996, resulting in a gain in competitiveness. From this date, we observe that the misalignment of the real effective exchange rate has reduced, this is due to the policy of stabilizing the real exchange rate and to a prudent

Year XXIV no. 80

June 2021 
macroeconomic policy, however, the misalignment of the exchange rate actual workforce remains relatively unstable (it varied from -3\% in 1991 to $8 \%$ in 2006), so we can say that, during the 1990 s, Tunisia was unable to maintain its competitiveness. Since 2004, we have noticed an overvaluation of the dinar despite the adoption of a depreciation policy, but this overvaluation remains relatively low (less than $2 \%$ ). The depreciation of the exchange rate began towards the end of 2000- early 2001. Indeed, during this period, Tunisia experienced a series of negative shocks, in particular the events of September $11^{\text {th }}, 2001$ and the synagogue attack in Djerba in 2002. Also, the Euro appreciated rapidly against the Dollar which favored the depreciation of the Tunisian Dinar. In fact, from the 2000s, the Central Bank of Tunisia began to make the exchange rate more flexible by reducing these interventions on the foreign exchange market, which explains the reaction of the exchange rate to external shocks. Another effect of these shocks, the gradual elimination of customs barriers under the free trade agreement with the EU, prompted the authorities to allow the dinar to depreciate to promote exports. In conclusion, we can say that Tunisia reduced its misalignment (between $0 \%$ and $15 \%$ ) from the year 2003 when it started to open its foreign exchange market and liberalize its financial market. Therefore, it was the easing of the exchange rate policy that enabled Tunisia to reduce the misalignment of the real effective exchange rate.

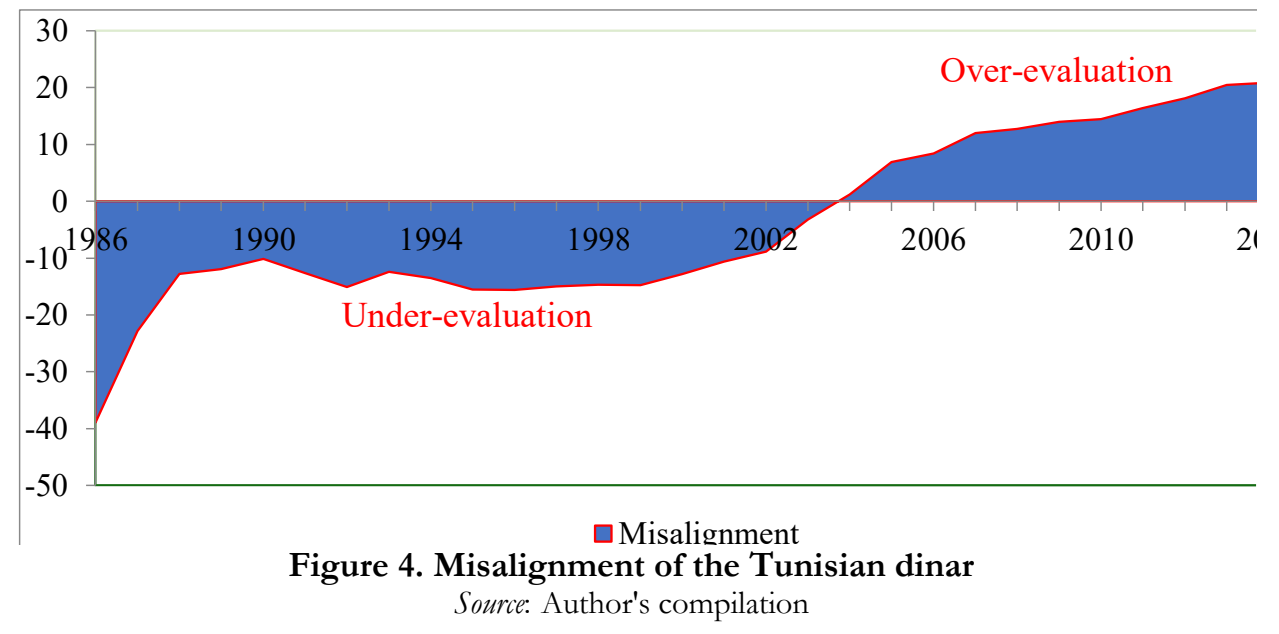

Figure 4 measures the size of the deviations between the observed real exchange rate and the equilibrium real exchange rate. Positive values of these deviations correspond to an overvaluation of the Tunisian dinar, while values below zero indicate an undervaluation of the currency relative to the equilibrium exchange 
rate. The periods of over and underestimation of the real effective exchange rate is represented in the following table over the thirty years mentioned:

Table 3. Over and Under Evaluation Period

\begin{tabular}{|c|c|c|}
\hline \multicolumn{3}{|c|}{ REER } \\
\hline PERIOD & MISALIGNMENT & STATUS \\
\hline $1986-2003$ & $-14.53 \%$ & UNDER EVALUATION \\
$2004-2015$ & $+13.38 \%$ & OVER EVALUATION \\
\hline
\end{tabular}

More precisely, we distinguish at least two phases:

- The first phase, 1986-2003, is characterized by the country's commitment to the structural adjustment plan and the adoption of new rules for the market economy and the liberalization of the economy. Likewise, following the imperatives of economic recovery and fluctuations, particularly of the dollar, the dinar underwent an official devaluation of $10 \%$ in 1986, followed by a sustained slide until 1992. The objective pursued by such a policy is to stabilize the REER vis-à-vis partner countries and correct the inflation differential between Tunisia and these countries. As shown in the figure below, such measures have resulted in a downward trend in the dinar's real exchange rate and a clear stabilization of the NEER reinforced by the performances achieved in terms of inflation leading to a reduction in the inflationary differential with partner countries. As for the NEER, the variations recorded are similar to the REER.

- The second phase, 2004-2015, is the period of the euro. The analysis of the price competitiveness of Tunisia according to the figure below shows that the downward trend which characterizes the REER of Tunisia has had the effect of improving competitiveness. This is very clear and is justified by the fact that the REER has never marked an appreciation in the whole last decade when the country is supposed to have gained a good experience in the market economy during the nineties.

\section{Conclusion and recommendations}

Tunisia has adopted various exchange rate policies since the collapse of the Bretton Woods system to maintain or improve its competitiveness. However, this goal only began to be realized when it started liberalizing its exchange rate in 2001. Our econometric results show that the equilibrium level of the long-run exchange rate depends on productivity, the terms of trade and government spending. From a quantitative perspective, productivity has a positive and significant effect on the real exchange rate. In contrast, the terms of trade and government spending are 
negatively correlated with the real exchange rate. Two sub-periods largely mark these years, that of a positive misalignment (undervaluation) from 1986 to 2003 followed by another negative misalignment (overvaluation) from 2004 to 2015 . Indeed, the calculation of the misalignment via the estimated model shows the evolution of the real exchange rate misalignment in Tunisia over the period 19862015. This development is persistent and recurring but also decreasing and at a low level. Such a result can be explained by Tunisia's orientation towards the flexibility of the real exchange rate which in turn is likely to reduce the degree of imbalance of the real exchange rate. Likewise, the Tunisian authorities must adopt gradual reforms in their liberalization and financial integration decisions and they are called upon to strengthen their trade and exchange policies to meet the challenge of the new international financial architecture. Finally, regarding the misalignment, we found the difference between the observed exchange rate and the equilibrium exchange rate is very low, especially since the introduction of the structural adjustment plan. This means that the monetary authorities apply a policy of the flexible, managed and prudent exchange rate. Indeed, since January 2008, a free trade area has been established between Tunisia and the European Union and customs duties on imports have been removed, which should lead to an increase in imports. Therefore, improved exports require a competitive and flexible exchange rate otherwise a large current account imbalance may occur.

\section{References}

Adams C. and Gros D. (1986): "The consequences of real exchange rate rules for inflation: some illustrative examples », IMF Staff Paper, 33, 439-476.

Baffes J., Elbadawi I. and O'Connell S. (1997): «Single Equation Estimation of the Equilibrium Real Exchange Rate», Policy Research Working Paper, Washington D.C.: The World Bank.

Branson W.H., Halttunen H. and Masson P. (1977): «Exchange rates in the short run: the dollar/Deutschmark rate», European Economic Review, Vol. 10, 303-324.

Clark P.B. and MacDonald R. (1998): " Exchange Rates and Economic Fundamentals: A Methodological Comparison of BEERs and FEERs ", IMF Working Paper 98/67, Washington: International Monetary Fund.

Devarajan S., Delfin S. Go and Hong-yi Li (1998): "Import-Substitution and Export- Transformation Elasticities ", The World Bank, Development Research Group, Washington, D.C.

Domaç I. and Shabsigh G. (1999): "Real Exchange Rate Behaviour and Economic Rate Growth: Evidence from Egypt, Jordan, Morocco and Tunisia », IMF Working Paper, WP/99/40, Washington D.C, p. 24.

Year XXIV no. 80

June 2021 
Edwards S. (1988): «Real and monetary determinants of real exchange rate behavion», Journal of Development Economics, 29, 311-341.

Edwards S. (1989): «Real Exchange Rates, Devaluation and Adjustment: Exchange Rate Policy in Developing Countries», Cambridge: MIT Press.

Edwards S. (2000): «Exchange Rate Regimes, Capital Flows and Crisis Prevention», National Bureau of Economic Research, p. 68.

El Badawi I.A. (1994): «Estimating Long-Run Equilibrium Exchange Rates Estimating Equilibrium Exchange Rates», John Williamson, Editor. Institute for International Economics, Washington, D.C.

Fanizza D., Laframboise N., Martin E., Sab R. and Karpowicz I. (2002): «Tunisia's experience with real exchange rate targeting and the transition to a flexible exchange rate regime», IMF, Working Paper $n^{\circ} 02 / 190$, November.

Fatma Marrakchi Charfi (2008): «Taux de change réel d'équilibre et mésalignements: Enseignements d'un modèle VAR-ECM pour le cas de la Tunisie», PANOECONOMICUS, 2008, 4, 439-464.

Frait J. and Komárek L. (2001): «Real exchange rate trends in transitional countries», Warwick Economic Research Papers, N596, p. 35.

http://wrap.warwick.ac.uk/1585/1/WRAP_Frait_twerp596.pdf

Gagnon J.E. (1996): «Net Foreign Assets and Equilibrium Exchange Rates: Panel Evidence», Board of Governors of the Federal Reserve System, International Finance Discussion Paper, $n^{\circ} 574$.

Hanna K.E.D. (2001): «Competitiveness in the MENA Region: Egypt, Morocco, Tunisia, Turkey», Seconde Conference du FEMISE, Marseille, 29 et 30 Mars 2001

Jongwanich J. (2009): «Equilibrium Real Exchange Rate, Misalignment, and Export Performance in Developing Asia», ADB Economics Working Paper Series, No. 151, p. 44.

Kaminsky G., Lizondos S. and Reinhart, C. (1997): «Leading indicators of currency crisis», IMF Working Paper, 97/99.

Montiel P.J. and J. D. Ostry (1991): «Macroeconomic implications of real exchange targeting in developing countries», IMF Staff Papers, 38 (4), 872 900 .

Razin O. and Collins S.M. (1997): «Real Exchange Rate Misalignments and Growth", http://www.tau.ac.il/ razin/ofair.paper.PDF, p. 21.

Robinson, J. (1937): «The Foreign Exchanges», published in Readings in the Theory of International Trade, Homewood: Irwing, 83-103.

Safra M. and Ben Marzouka T. (1987): «L'instabilité du Taux de Change et ses Effets sur le Commerce Extérieur: le Cas de la Tunisie et du Maroc», Finance et développement au Maghreb/ N², Décembre, 19-20.

Year XXIV no. 80

June 2021 
Stein J.L. and Allen P.R. (1995): «Fundamental Determinants of Exchange Rates », Oxford, New York: Oxford University Press, Clarendon Press.

Williamson J. (1983): «The exchange rate system», Policy Analyses in International Economics, 5, Washington: Institute for International Economics. Washington, DC (MIT Press, Cambridge, MA, 1983) p. 110.

Williamson J. (1994): «Estimating Equilibrium Exchange Rates, Institute for International Economics», Washington D.C. 